Cletus C. Coughlin and Kees Koedijk

Cletus $C$. Coughlin is a research officer at the Federal Reserve Bank of St. Louis. Kees Koedijk is a professor of economics at Erasmus University, Rotterdam. Thomas A. Pollmann provided research assistance.

\title{
What Do We Know About the Long-Run Real Exchange
}

\section{Rate?}

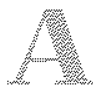

REAL EXCHANGE rate is defined as the foreign currency price of a unit of domestic currency (that is, the nominal exchange rate) multiplied by the ratio of the domestic to the foreign price level. The real exchange rate has been at the center of economic policy discussions in the 1980 s for at least two reasons. First, this relative price has been more variable in the floating-rate period than in the preceding era of fixed (nominal) exchange sates. ${ }^{3}$ Second, this price is related to international trade pat. terns because the competitive position of an individual exporting (import-competing) firm in a country is affected adversely by an appreciating (depreciating) real exchange rate. ${ }^{2}$

Despite much research, however, there is no consensus on which variables cause changes in the real exchange rate. Like any asset price, real exchange rates are related to the determinants of the relevant supply and demand curves now and in the future. ${ }^{3}$ With real exchange rates, the relevant determinants are those affec" ting the relative supplies and demands for the currencies of two countries. Claims have been made, however, that the real exchange rates
1See Frankel and Meese (1987) and Dornbusch (1989) for surveys of this literature. As noted by Dornbusch, the increased variability and lack of knowledge have contributed to divergent policy recommendations, which include a return to some form of a managed exchange-rate system, taxes on foreign exchange transactions as well as doing nothing.

2The U.S. dollar has been at the center of the controversy, with the dollar allegedly being undervalued in the late 1970 s/early 1980 s and overvalued in the mid-1980s. During the period of undervaluation, U.S. tradeable goods industries were stimulated and induced to overexpand. The costs of this alleged overexpansion were exacerbated by the subsequent overvaluation, which resulted in layoffs, plant closings and bankruptcies in these same industries.

3This elementary principle is ignored when the exchange rate in macroeconomic settings is treated as an ex- ogenous rather than endogenous variable. For example, a standard assertion is that a depreciating dollar boosts U.S. manufacturing output. A declining dollar is expected to raise the dollar prices of U.S. imports and lower the foreign currency prices of U.S. exports. Consequently, consumption and production of U.S. exports and importcompeting goods would rise. This analysis is taulty because changes in the value of the dollar are not independent of U.S. industrial developments and, in fact, can be the direct result of industrial developments. For example, an economic policy that boosts productive capacity can generate a positive relationship between the value of the dollar and U.S. manufacturing output. Details on this argument can be found in Tatom (1988). 
often differ substantially from levels consistent with the underlying economic fundamentals and that these differences persist for long periods.

A primary goal of our research is to provide an elementary understanding of the major theoretical approaches to the determination of longrun real exchange rates. These approaches identify numerous variables that have been tested for their relationships to the changing values of the real exchange rate. Empirically, we examine the six bilateral real exchange rates among the United States, West Germany, Japan and the United Kingdom. ${ }^{4}$ Using a data set covering approximately the same time period, we make a straightforward comparison of the three primary approaches and present a clear picture of what can be said about the determinants of real exchange rates.

Research to explain movements in the longrun real exchange rate is unnecessary if purchasing power parity (PPP) holds in the long run. Thus, we begin by reviewing the literature on PPP in the long run. This provides a natural starting point from which to examine the different theoretical approaches to real exchange rate determination and the major empirical findings. Next, we undertake unit root and cointegration tests to examine whether long-run relationships exist between the real exchange rate and some of its potential determinants.

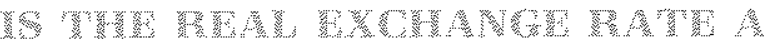

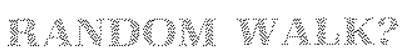

As a point of departure, it is useful to define the real exchange as it is used throughout this paper. A standard representation expresses all variables in logarithms, so that a real exchange rate, $\mathrm{q}$, is defined as follows:

(1) $\mathrm{q}=\mathrm{e}+\mathrm{p}-\mathrm{p}^{*}$,

where $\mathrm{e}$ is the foreign currency price of a unit of domestic currency, $p$ is the domestic price level as measured by the consumer price index and $p^{*}$ is the similarly measured foreign price level. ${ }^{5}$

Since the advent of flexible exchange rates in 1973, real exchange rates have been more variable than they were previously. This point is illustrated in figure 1 over 1957 to 1988 for the pound/dollar, mark/dollar and yen/dollar real exchange rates. The increased variability has induced many researchers to focus on the fundamental relationships that determine real exchange rates.

The concept of purchasing power parity has been one of the most important building blocks for nominal, as well as real, exchange rate modeling during the $1970 \mathrm{~s}$ and $1980 \mathrm{~s}$. In its absolute version, PPP states that the equilibrium value of the nominal exchange rate between the currencies of two countries will equal the ratio of the countries' price levels. ${ }^{6}$ Thus, a deviation of the nominal exchange rate from PPP has been viewed as a measure of a curren$c y$ 's over/undervaluation. In its relative version, PPP states that the equilibrium value of the nominal exchange rate will change according to the relative change of the countries' price levels. A noteworthy implication of both versions of PPP is that the real exchange rate will remain constant over time.

Economists have debated whether PpP applies in the short run, long run or neither. By the end of the 1970s, PPP, at least in the short run, was rejected convincingly by the data. ${ }^{7}$ Whether PPP in the long run can be rejected is less clear. A standard theoretical argument in support of
${ }^{4}$ Our selection of countries is based on research by Koedijk and Schoiman (1989), which indicates that the movements of real exchange rates for 15 industrial countries can be partitioned into four groups led by the United States, West Germany, Japan and the United Kingdom.

5Wholesale price indexes are also frequently used in the calcuiation of real exchange rates. The use of wholesale rather than consumer prices can generate different results. For an example, see McNown and Wallace (1989). For a brief discussion of why a broad-based measure of prices such as consumer prices is more appropriate than one of wholesale prices in calculating real exchange rates, see Cox (1987).

6 More generally, PPP has been stated in Edison and Klovland (1987) as $E=K\left(P / P^{*}\right)$, where $E$ is the exchange rate (domestic currency value per unit of foreign currency), $P$ is an index of domestic prices, $P^{*}$ is an index of foreign prices and $K$ is a scalar. In this view, the PPP hypothesis is a homogeneity postulate of monetary theory rather than an arbitrage condition. Thus, a monetary disturbance causes an equiproportionate change in money, commodity prices and the price of foreign exchange, while relative prices are unchanged. The influence of real factors on the relationship between exchange rates and national pice levels is captured by $K$, which is a function of structural factors that can alter the relative prices of goods.

7 See Adler and Lehmann (1983) for the references underlying this consensus. 
Figure 1

Real Bilateral Exchange Rates in the Fixed and Floating Rate Periods
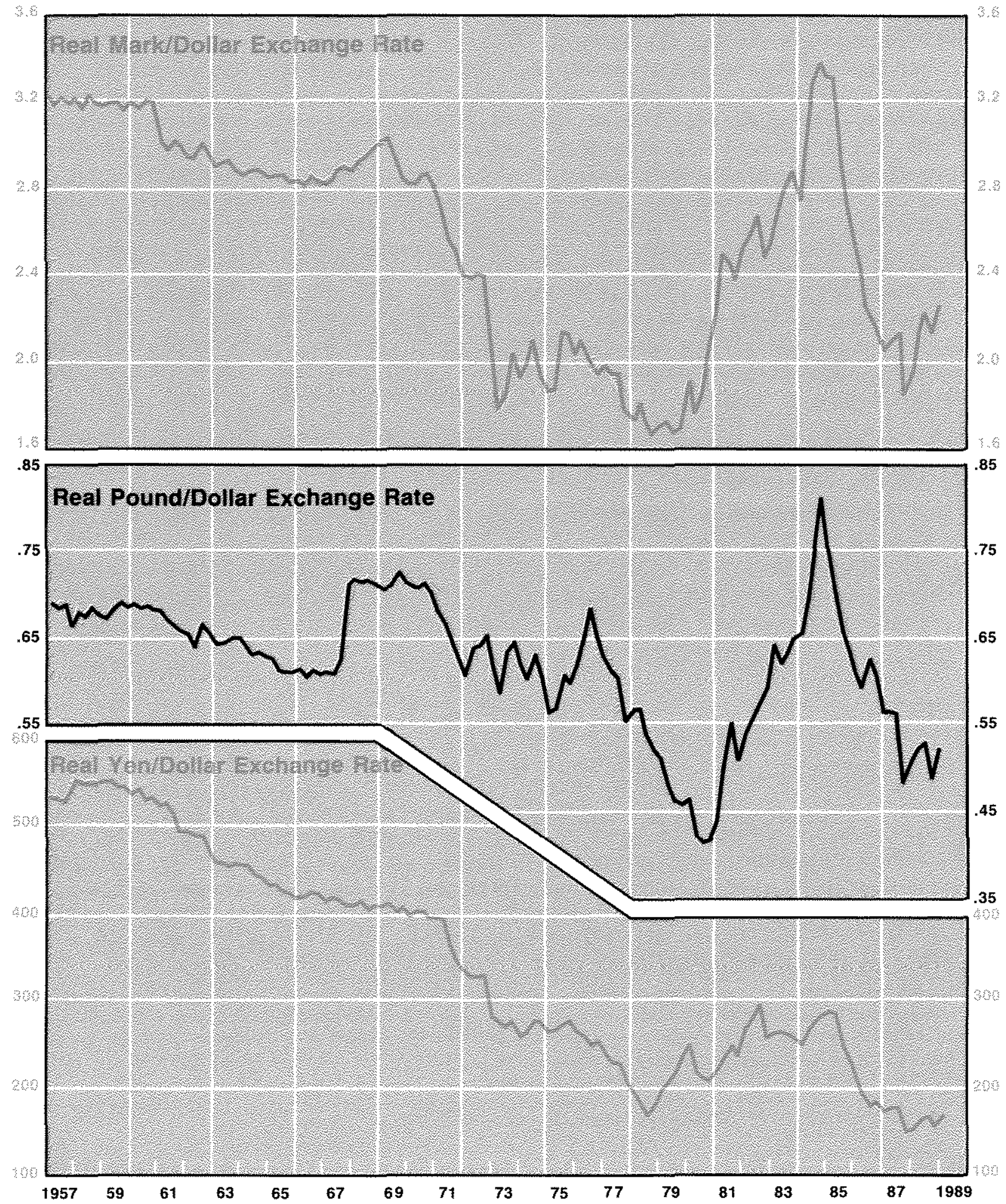
PPP is that deviations from parity, assuming zero transportation costs and no trade barriers, indicate profitable opportunities for commodity arbitrage. Deviations from PPP imply that the same good, after adjusting for the exchange rate, will sell at different prices in two locations. Simultaneously buying the good in the low-price country and selling the good in the high-price country will force the nominal exchange rate to PPP and the real exchange rate to some constant value.

The chief issue is whether the real exchange rate returns over time to a fixed value, the long-run equilibrium real exchange rate. On the other hand, it is possible that the equilibrium value of the real exchange rate is not constant over time, but instead changes in response to changes in some fundamental economic variables. For example, an increase in a country's real interest rate, ceteris paribus, could cause an appreciation of the country's real exchange rate.

One conclusion, however, is clear: if the real exchange rate follows a random walk, long-run PPP does not hold. A variable is said to follow a random walk if its value in the next period equals its value in the current period plus a random error that cannot be forecast using available information. If the real exchange rate follows a random wakk, then it will not return to some average value associated with PPP over time. In fact, its deviation from the PPP value becomes unbounded in the long run.

The unit root test is a common procedure to use in determining whether a variable follows a random walk ${ }^{8}$ If the existence of a unit root cannot be rejected, then the variable is said to follow a random walk. Using data from various developed countries, recent studies by Darby (1983), Adler and Lehmann (1983), Huizinga (1987), Baillie and Selover (1987) and Taylor (1988) could not reject the unit root hypothesis for the real exchange rate in the current floating rate period and, hence, rejected the notion of long-run PPP.

The issue, nevertheless, remains controversial. One reason is that some researchers have found evidence to reject the random-walk hypothesis in some cases. ${ }^{9}$ In addition, doubts about the power of standard tests to discriminate between true random walks and near random walks have been raised. For example, Hakkio (1986) demonstrated that, when the real exchange rate differs modestly from a random walk, the results of standard tests are biased in favor of the random-walk hypothesis. In other words, there is a high probability of failing to reject the random-walk hypothesis even if it is false. ${ }^{10}$

Another possibility is that the current floatingrate period is too brief to assess accurately the validity of PPP. Lothian (1989), using unit root tests and annual data for over 100 years for Japan, the United States, the United Kingdom and France, found that real exchange rates tended to return to their long-run equilibrium values, but that the period of adjustment was quite long. For example, adjustment periods ranging from three to five years were found. Consequently, the current floating-rate period might not be long enough to identify the longrun tendency of the real exchange rate to return to an equilibrium.
8The issue is whether the real exchange rate is stationary. If the real exchange rate is stationary, then random disturbances have no permanent effects on this rate. If the real exchange rate is nonstationary, then there is no tendency for this rate to return to an "average" value over time. To determine whether the real exchange rate is stationary, a standard procedure is to use the Dickey-Fuller test for unit roots. This procedure is described later in the text.

9Examples include Cumby and Obstfeld (1984) and Frankel (1986). Using monthly data between September 1975 and May 1981, Cumby and Obstfeld rejected the random-walk hypothesis for the real exchange rate between the United States and Canada. On the other hand, they were unable to reject the random-walk hypothesis for the real exchange rate when the United States was paired with each of the following countries-United Kingdom, West Germany, Switzerland and Japan. Frankel (1986) rejected the random-walk hypothesis for the real U.S. dollar/British pound exchange rate using annual data between 1869 and 1984, but was not able to reject the typothesis using data for 1945-1984.
:0The preceding problem motivated Sims (1988) to develop a new test for discriminating between true and near random walks. Applying this new test, Whitt (1989) was able to reject the hypothesis that the real exchange rate was a random walk. A forthcoming issue of the Journal of Econometrics, however, concludes that the appropriateness of Bayesian approaches in detecting unit roots remains in doubt because many questions, some re. quiring highly technical responses, have not been answered. Consequently, we did not use this technique in our analysis. 


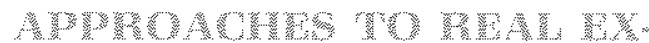

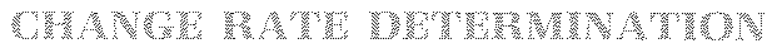

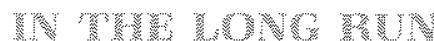

Our goal is not to resolve the preceding controversy about PPP in the long run. Rather, it is to examine, as well as extend empirically, the research efforts of those who have provided models that allow for the long.run real exchange rate to vary over time. In other words, our goal is to examine the attempts by researchers skeptical about PPP in the long run to explain movements in the long-run real exchange rate. Two real approaches and a monetary approach to exchange-rate determination have been used to explain movements in the equilibrium real exchange rate. The first real approach is concerned with movements in the real ex. change rate that arise from incorporating the difference between tradeable and non-tradeable goods prices. The other real approach deals with the implications of incorporating a balance of payments constraint. The monetary approach, in contrast, focuses on the relationship between real exchange rates and real interest rates.

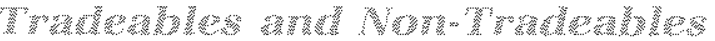

Absolute PPP implies that the equilibrium value of the nominal exchange rate between the currencies of two countries would equal the ratio of the countries' price levels, which is commonly measured by the respective consumer price indexes. Ignoring transportation costs, free international trade eliminates the price difference between the same good in two countries; however, price differences across countries for non-traded goods may persist and may change substantially over time. Frequently, this possibility is referred to as PPP holding only for internationally traded goods; however, one could view this possibility as a substantial modification of PPP. To prevent confusion, we do not call this PPp, but rather characterize it as the law of one price for traded goods.

A simple model illustrating this approach is presented below. Let $p$ be the logarithm (log) of the overall price level, and $\mathrm{p}_{\mathrm{T}}$ and $\mathrm{p}_{\mathrm{NT}}$ be the logs of the price levels of traded and non-traded goods; an asterisk denotes the foreign country. The overall price level is related to the prices of tradeable and non-tradeable goods by

(2) $\mathrm{p}=(1-\alpha) \mathrm{p}_{\mathrm{T}}+\alpha \mathrm{p}_{\mathrm{NT}}$

and

(3) $\mathrm{p}^{*}=(1-\beta) \mathrm{p}_{\mathrm{T}}^{*}+\beta \mathrm{p}_{\mathrm{NT}}^{*}$

where $\alpha$ and $\beta$ denote the shares of the nontradeable goods sectors in the economies. ${ }^{11}$ Assuming the law of one price for tradeable goods,

(4) $e+p_{T}-p_{\mathrm{T}}^{*}=0$,

where $\mathrm{e}$ is the log of the nominal exchange rate, measured as the foreign currency price of a unit of domestic currency. ${ }^{12}$

By substituting equations 2,3 and 4 into equation 1, the real exchange rate, $q$, can be written as

(5) $\mathrm{q}=-\alpha\left(\mathrm{p}_{\mathrm{T}}-\mathrm{p}_{\mathrm{NT}}\right)+\beta\left(\mathrm{p}_{\mathrm{T}}^{*}-\mathrm{p}_{\mathrm{NT}}^{*}\right)$.

Thus, the real exchange rate depends on relative prices between tradeable and non-tradeable goods as well as the sizes of the non-tradeable goods sectors in the two countries. Our focus is restricted to the possibility that persistent differences between the price changes of tradeable and non-tradeable goods across the two economies can cause real exchange rate movements.

Two main proxies, one using relative prices, the other using output measures, have been used to measure the tradeables/non-tradeables distinction. As Wolff (1987) has noted, a stan. dard empirical proxy in analyzing relative prices in a world with internationally traded and nontraded goods is the ratio of wholesale prices to consumer prices. The reasoning is straightforward. Wholesale price indexes generally pertain to baskets of goods that contain larger shares of traded goods than consumer price indexes do. Consumer price indexes tend to contain relatively larger shares of non-traded consumer services. To date, however, empirical evidence on

\footnotetext{
"These indexes suggest that the price level is constructed as follows: $P=P^{(1-n)} P_{F T}^{a}$, where the upper-case Ps represent levels. Price indexes are not really constructed this way; however, following Hsieh (1982), this construction was chosen to simplity the derivation. Hsieh has argued that his empirical results were not distorted by this assumed construction because he used highly aggregated data.
}
12As a check, using wholesale prices for the prices of traded goods, we found that $e+p_{\mathrm{T}}-\mathrm{p}_{\mathrm{r}}^{*}$ was not stationary. Thus, one of the building blocks for this approach does not hold for our data. In addition, even if one were to define the real exchange rate using wholesale rather than consumer prices, PPP would not appear to hold in the long run.


the importance of relative prices in explaining real exchange rate movements is lacking.

The other proxy for the tradeables/non. tradeables distinction was highlighted by Balassa (1964). Balassa assumed that the law of one price held for traded goods, that wages in the tradeable goods sector are linked to productivity and that wages across industries are equal. These assumptions cause the price of non-tradeable goods relative to tradeable goods to increase more over time in a country with high productivity growth in the tradeable goods sec. tor than in a country with low productivity growth. Such a productivity differential, in conjunction with a general price index that covers both traded and non-traded goods, will result in. a real exchange rate appreciation for fast. growing countries even with the prices of traded goods equalized across countries.

For the empirical application of the productivity approach, Balassa suggested that there should be a positive link between the real exchange rate and real per capita gross national product, which assumes that inter-country productivity differences are reflected in per capita income levels. The effect of shifts in sectoral productivity have been investigated by Hsieh (1982) and Edison and Klovland (1987). Hsieh found that real exchange-rate changes for West Germany and Japan could be explained by differences in the relative growth rates of labor productivity between traded and non-traded sectors for these countries and their major trading partners.

Similarly, Edison and Klovland, using annual data, found a long-run equilibrium relation between the pound/Norwegian krone real exchange rate and the real output differential and between the real exchange rate and the commodity/service productivity ratio differential. The results of Edison and Klovland raise a number of interesting questions because the data cover a period that is both long, 1874-1971, and does not encompass the current floatingrate period. Consequently, one is left wondering whether 15 years of data, which require the use of data more frequent than annual observations, is sufficient to reach strong conclusions about the current period and whether Edison and Klovland's results would be altered by data from the current period.

\section{W

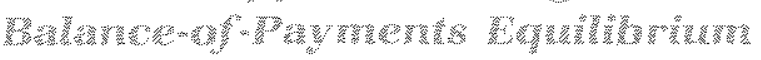

An alternative real approach to analyze movements in the real exchange rate is to include a balance-of payments constraint. ${ }^{13}$ This approach focuses on the theoretical relationship between changes in the equilibrium real exchange rate and changes in the current account. The longrun equilibrium real exchange rate is the rate that equilibrates the current account in the long run. Recall that balance-of-payments accounting ensures that the current account is identical to the negative of the capital account, which is simply the rate of change of net foreign holdings. Thus, the current account equilibrium in the long run is determined by the rate at which foreign and domestic residents wish to change their net foreign asset positions in the long run.

Any fundamental economic factor that in. fluences the current account affects the real exchange rate. Consequently, the long-run equilibrium real exchange rate depends on real factors-whose changes can either be anticipated or unanticipated-that cause shifts in the demand for and supply of domestic and foreign goods. The most notable example is the relative output differential. Relatively faster output growth domestically will induce an appreciation of the long-run equilibrium real exchange rate.

A key aspect of this approach focuses on the possibility that unanticipated changes in the cur. rent account affect the long-run real exchange rate. Unexpected changes in the current account are assumed to reflect changes in under. lying determinants that, in turn, require offsetting changes in the real exchange rate to ensure current account equilibrium in the long run. $A$ long-run balance-of-payments constraint suggests that any revisions in expectations about the long-run values of variables that affect the balance of payments affect the expected value of the long-run real exchange rate. As Isard (1983) notes, the substantial changes in the pelative price of oil during the 1970 s are excellent examples of how unexpected changes in a determinant of the current account caused revised expectations about the long-run real exchange rate.

An illustration highlighting the importance of unanticipated current account changes is pre.

\footnotetext{
${ }^{13}$ Examples may be found in Isard (1983) and Frenkel and Mussa (1985).
} 
sented by Dornbusch and Fischer (1980). In their model, a current account surplus causes a rise in wealth through the net inflow of foreign assets. Assuming the rise in wealth is unanticipated, excess demand in the domestic goods market occurs. In turn, an increase in the real exchange rate is required for the new goods market equilibrium. This increase induces the necessary shift from domestic to foreign goods by domestic and foreign consumers to eliminate the excess demand.

Hooper and Morton (1982) use this framework to relate changes in the real exchange rate to economic fundamentals. They use the cumulated current account as a determinant of the long.run equilibrium real exchange rate. In their model, unanticipated changes in the current account are assumed to provide information about shifts in the underlying determinants that necessitate offsetting shifts in the real exchange rate to maintain current account equilibrium in the long run. Consistent with this balance-ofpayments approach, their results indicate that, between 1973 and 1978, movements in the current account have been a significant determinant of movements in the real exchange rate for the U.S. dollar, predominantly through changes in expectations.

\section{The Wonger}

As mentioned previously, the monetary approach focuses on the relationship between real exchange rates and real interest rates. A straightforward exposition of this approach, which can be found in Meese and Rogoff (1988), is based on models developed by Dornbusch (1976), Frankel (1979) and Hooper and Morton (1982). These models are "sticky-price" versions of the monetary model of exchange rates; they assume that prices of all goods adjust slowly in response to disturbances. Thus, temporary deviations in the real exchange rate from its longrun equilibrium value (that is, purchasing power parity) are possible.

These temporary deviations necessitate an exchange-rate adjustment mechanism to restore the long-run equilibrium value. A standard as- sumption is that the deviations are eliminated at a constant rate. The adjustment process can be represented as follows:

(6) $\mathrm{E}_{\mathrm{t}}\left(\mathrm{q}_{\mathrm{t}+\mathrm{k}}-\overline{\mathrm{q}}_{\mathrm{t}+\mathrm{k}}\right)=\theta^{\mathrm{k}}\left(\mathrm{q}_{\mathrm{t}}-\overline{\mathrm{q}}_{\mathrm{t}}\right), 0<\theta<1$,

where $\mathrm{E}$ is an expectations operator, the subscripts designate the time period, $q$ is the logarithm of the real exchange rate, the bars indicate values that would prevail if all prices were fully flexible instantaneously and $\theta$ is the speed-of-adjustment parameter. Consequently, there is a monotonic adjustment of the real exchange rate to the long-run equilibrium, $\bar{q}_{i}$, over time with lower values of $\theta$ indicating a quicker adjustment process. ${ }^{14}$

The longarun equilibrium value changes with random real shocks; however, assuming all real shocks follow random-walk processes, these shocks do not affect the expected long-run equilibrium exchange rate. Consequently,

(7) $E_{1} \bar{q}_{1+k}=\bar{q}_{1}$.

Substituting equation 7 into equation 6 yields

(8) $\mathrm{q}_{\mathrm{s}}=d\left(\mathrm{E}_{\mathrm{t}} \mathrm{q}_{\mathrm{t}+\mathrm{k}}-\mathrm{q}_{\mathrm{s}}\right)+\overline{\mathrm{q}}_{\mathrm{t}}$

where $\delta=1 /\left(\theta^{k}-1\right)<-1$. The observed real exchange rate is its temporary deviation from its long-run equilibrium value plus its long-run equilibrium value.

To complete the model, uncovered interest parity is assumed. ${ }^{15}$ This assumption is expressed as follows:

(9) $\mathrm{E}_{\mathrm{t}} \mathrm{e}_{\mathrm{t}+\mathrm{k}}-\mathrm{e}_{\mathrm{t}}={ }_{k} \mathrm{r}_{\mathrm{q}}^{*}-{ }_{\mathrm{k}} \mathrm{r}_{\mathrm{t}}$,

where $e$ is the logarithm of the nominal exchange rate (foreign currency per domestic currency unit), ${ }_{k} r_{t}$ is the $k$-period nominal interest rate at time $\mathrm{t}$ and the asterisk denotes a foreign value. In other words, changes in the nominal exchange rate are directly related to nominal interest rate differentials. As domestic nominal interest rates rise relative to foreign rates, the nominal exchange rate of the domestic country is expected to depreciate.

Equation 9 implies that the expected change in the real exchange rate reflects the expected real interest rate differential. In symbols,

\footnotetext{
${ }^{14}$ For example, a comparison of $\theta .6$ with $\theta=.4$ after two periods reveals that, in the former case, the expected difference between the actual and long-run equilibrium is 36 of the difference in the current period, while in the latter case the expected difference is 16 of the difference in the current period.
}

15The appropriateness of this assumption can be ques. tioned. The uncovered interest parity assumption requires that the forward rate be an unbiased and efficient predicm tor of the future spot rate; however, the empirical results summarized by Bailie and McMahon (1989) suggest otherwise. 
(10) $\mathbf{E}_{t}\left(\mathbf{q}_{x+k}-\mathbf{q}_{k}\right)={ }_{k} R_{t}^{*}-{ }_{k} R_{t}$

where the k-period interest rate, ${ }_{k} R_{t}$ is the difference between the nominal interest rate less the expected rate of change in prices. Substituting equation 10 into equation 8 yields

(11) $q_{t}=\delta\left(_{k} R_{t}^{*}-{ }_{k} R_{t}\right)+\bar{q}_{t}$

Therefore, the essence of the monetary approach is that changes in the real exchange rate are directly related to changes in the real interest differential. As expected real domestic interest rates rise relative to foreign rates; the real exchange rate of the domestic country rises as well.

Equation 11 provided the foundation for various statistical tests by Meese and Rogoff (1988). As noted in the appendix, the measurement of expected real interest rates is problematic. While the sign of the relationship between the longterm real interest rate differential and the real exchange rate was consistent with theory, the relationship was not statistically significant.

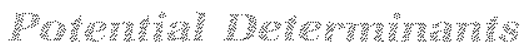

In summary, the existing literature points to five potential determinants of long-run real exchange rates that we use. The real approach identifies three possibilities, two based on the tradeables/non-tradeables distinction and one based on the balance-of-payments equilibrium. The proxies to measure the tradeables/nontradeables distinction have used the ratio of wholesale to consumer prices and real per cap. ita gross national product differences, while the cumulated current account difference is used for the balance of payments. The other major approach, the monetary approach, highlights the role of interest rate differentials. Both shortterm and long-term interest rate differentials across countries have been used.

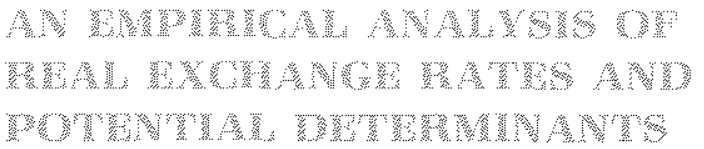

Our empirical analysis proceeds in two steps. First, using unit root tests, we test for the stationarity of the six real exchange rates that result from pairwise combinations of the foreign exchange rates of the United States, Japan, West Germany and the United Kingdom. The stationarity of five potential determinants for these exchange rates is examined as well. De. tails on the construction of these variables are presented in the appendix. Unless noted otherwise, we used monthly data from June 1973 to June 1988 for all variables. Thus, in the first step, we provide additional evidence on the ex" istence of PPP in the long run. Second, we test for cointegration between the real exchange rates and each of the potential determinants. The goal is to identify which variables, if any, from the models that we have reviewed explain variations in the real exchange rate over time.

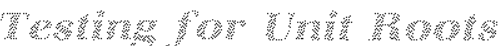

We used the test developed by Dickey and Fuller (1979) for testing for unit roots. ${ }^{16}$ In the present case, the test consists of regressing the first difference of the variable under considera* tion on its own lagged level, a constant and, to control for autocorrelation, an appropriate number of lagged first differences. ${ }^{17}$ The coefficient estimate on the lagged level is crucial, because the null hypothesis of a unit root implies that it is zero. The test-statistic is simply the estimate of the coefficient divided by its standard error. This test-statistic, which does not have the usual t-distribution, is then compared with critical values tabulated in Fuller (1976).

The results listed in table 1 show that we cannot reject the null hypothesis of a unit root for any of the bilateral real exchange rates. ${ }^{15}$ The
16See Trehan (1988) for a basic introduction to the intuition underlying unit roots and cointegration, as well as a practical illustration.

17 lf lagged first differences are needed, then the test is an "augmented" Dickey-Fuller test; otherwise, the test is simply a Dickey.Fuller test. The chosen lag length is the smallest lag length for which there is no autocorrelation.

${ }^{18}$ An important caveat concerning the interpretation of unit root tests is the extremely low power of these tests. Given a sample size of approximately 100 observations, the probability of accepting a coefficient of 1.0 on the lagged dependent variable when it is actually 0.95 is roughly 80 percent. Given the nature of the cointegration tesis, this caveat applies to these results as well. 
Table 1

\section{Unit Root Tests For Real Exchange Rates and Potential Determinants}

\begin{tabular}{|c|c|c|c|c|c|c|}
\hline Countries & $q$ & PW/PC-PW $/$ PC & GNP_GNP & TB TB & ASRS & $\mathrm{RL}-\mathrm{RL}$ \\
\hline UKUUS & 163 & 0.31 & 220 & 186 & 296 & 277 \\
\hline WGIUS & 127 & 0,13 & 151 & 272 & 315 & 152 \\
\hline JP/US & 088 & 1.44 & -0.47 & 0.10 & 3661 & 1,48 \\
\hline UKNG & 1.56 & 115 & 248 & 208 & 204 & 203 \\
\hline JPNG & 084 & 043 & 070 & 256 & 2921 & 2.68 \\
\hline UKJP & 127 & 068 & 0,32 & 191 & $4.40 t$ & 273 \\
\hline
\end{tabular}

1 Statistically significant at the 0.05 level

NOTE The test-statistic reported is minus the regressiont-statistic on a in a regression of the following general form:

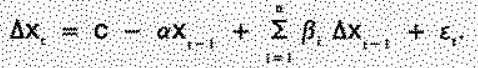

The lag length $\mathrm{n}$ is ehosen as the smallest value for which no autocorrelation exists. for a sample of 100 observations, the critical value for a significance level of 5 percent is 289.

real exchange rate measures are nonstationary since there is no tendency for the real exchange rates to return to an average value over time. Thus, consistent with studies cited previously, we reject long-run PPP.

Table 1 also contains the results of unit root tests for the potential determinants of real exchange rates. Both proxies used to measure the tradeables/non-tradeables distinction, the difference between countries of their ratios of wholesale to consumer prices (PW/PC-PW*/PC*) and real per capita gross national products (GNP-GNP*), are nonstationary. An identical conclusion is reached for the cumulated current account difference (TB- $\mathrm{TB}^{*}$ ), the proxy based on the balance-of-payments approach. In every case, we cannot reject the null hypothesis of a unit root.

The results for the two proxies based on the monetary approach are mixed. The difference between the short-term interest rates (RS-RS*) appears to be stationary in most cases. In only one case, United Kingdom/West Germany, the null hypothesis of a unit root is accepted. On the other hand, the difference between the long-term interest rates (RL-RL*) appears to be nonstationary because the null hypothesis of a unit root is accepted in each case.

\section{Thescher}

Even though the real exchange rate has a unit root, it is possible that there is a long-run relationship between it and other variables that also contain unit roots. For an equilibrium relationship to exist between these variables, the disturbances that cause nonstationary behavior in one variable must also cause nonstationary behavior in the other variable.

To test whether there is a long-run relation. ship between variables that contain unit roots, the residuals from an ordinary-least-squares regression between the variables can be examined for stationarity. In other words, a DickeyFuller test is performed on the residuals resulting from regressing one variable-the real exchange rate in our case-on a potential determinant. The first difference of the residual series is regressed on its lagged level, a constant and an appropriate number of lagged first differ. ences. A hypothesis test is performed using the coefficient estimate on the lagged level. If the null hypothesis of a coefficient of zero can be rejected, then the residuals are stationary. If the residuals are stationary, then the variables will not drift away from each other. Such variables are said to be cointegrated. Since cointegration 
Table 2

\section{Cointegration Tests of Real Exchange Rates and Potential Determinants}

\begin{tabular}{|c|c|c|c|c|c|}
\hline Countries & PWPCPW $/ P C$ & GNPGNP & $\mathrm{TB}_{\mathrm{TB}}$ & ns $n s^{*}$ & $\mathrm{RL} \mathbf{R L}$ \\
\hline UKUS & 162 & 164 & 157 & 183 & 171 \\
\hline waIUs & 149 & 153 & 164 & 245 & 3121 \\
\hline SPIUS & 190 & 1,07 & 107 & 121 & 123 \\
\hline UWWG & 276 & 211 & 2.29 & 211 & 2,37 \\
\hline JPIWG & 263 & 3.50 & 2.06 & 1,39 & 133 \\
\hline UKJP & 241 & 1,49 & 132 & 151 & 180 \\
\hline
\end{tabular}

tests are oriented toward rejecting any long-run relationship, finding cointegration suggests the existence of a significant statistical link between the variables.

Table 2 shows the results of such cointegration tests. Overall, there is little evidence to in. dicate that the examined variables explain variations in the real exchange rate over time. Real exchange rates and the differences between ratios of wholesale to consumer prices across countries do not appear to be cointegrated. Despite augmented Dickey-Fuller statistics that approach the critical value in two cases, United Kingdom/West Germany and West Germany/Japan, the residuals are nonstationary in each case. The real exchange rate and the difference between the real per capita gross national products are cointegrated only for West Germany and Japan. The cointegration tests also reveal that the residuals are nonstationary for both the cumulated trade balance and short-term interest rate differences.

One interesting result is the significant relationship between the real exchange rate and the long-term real interest differential for the United States and West Germany. This result contrasts with Campbell and Clarida (1987) and Meese and Rogoff (1988) who fail to find cointegration between these variables. Since our pro$\mathrm{xy}$ for the long-term real interest differential is exactly the same as that used by Meese and Rogoff, the additional 18 more recent months of data seem to account for the different result. ${ }^{19}$

In figure 2, we have plotted the long-term real interest differential between the United States and Germany and the real mark/dollar exchange rate. As is apparent from the figure, there is a strong link between these variables: a higher long-term real interest rate in the United States relative to Germany means a stronger dollar.

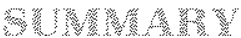

Unfortunately, as our review of a host of studies reveals, little is known about the determinants of real exchange rates in the long run. Our systematic survey of five potential explanatory variables suggests that no approach to this issue is satisfactory. For example, for certain exchange rates, the real approach based on the tradeables/non-tradeables distinction yields evidence of an equilibrium relationship between

19The sample used by Meese and Rogoff (1988), as stated in their table $V$, terminated in December 1985 , while our sample using long-term interest differentials between West Germany and the United States terminated in June 1987. When we delete these 18 months of observations, the regression t-statistic is 2.77 rather than the 3.12 reported in our table 2. Like Meese and Rogoff, we would fajl to find cointegration. 


\section{Figure 2 \\ Colntegration of Real Mark/Dollar Exchange Rate and Real Long Interest Rate Differential}

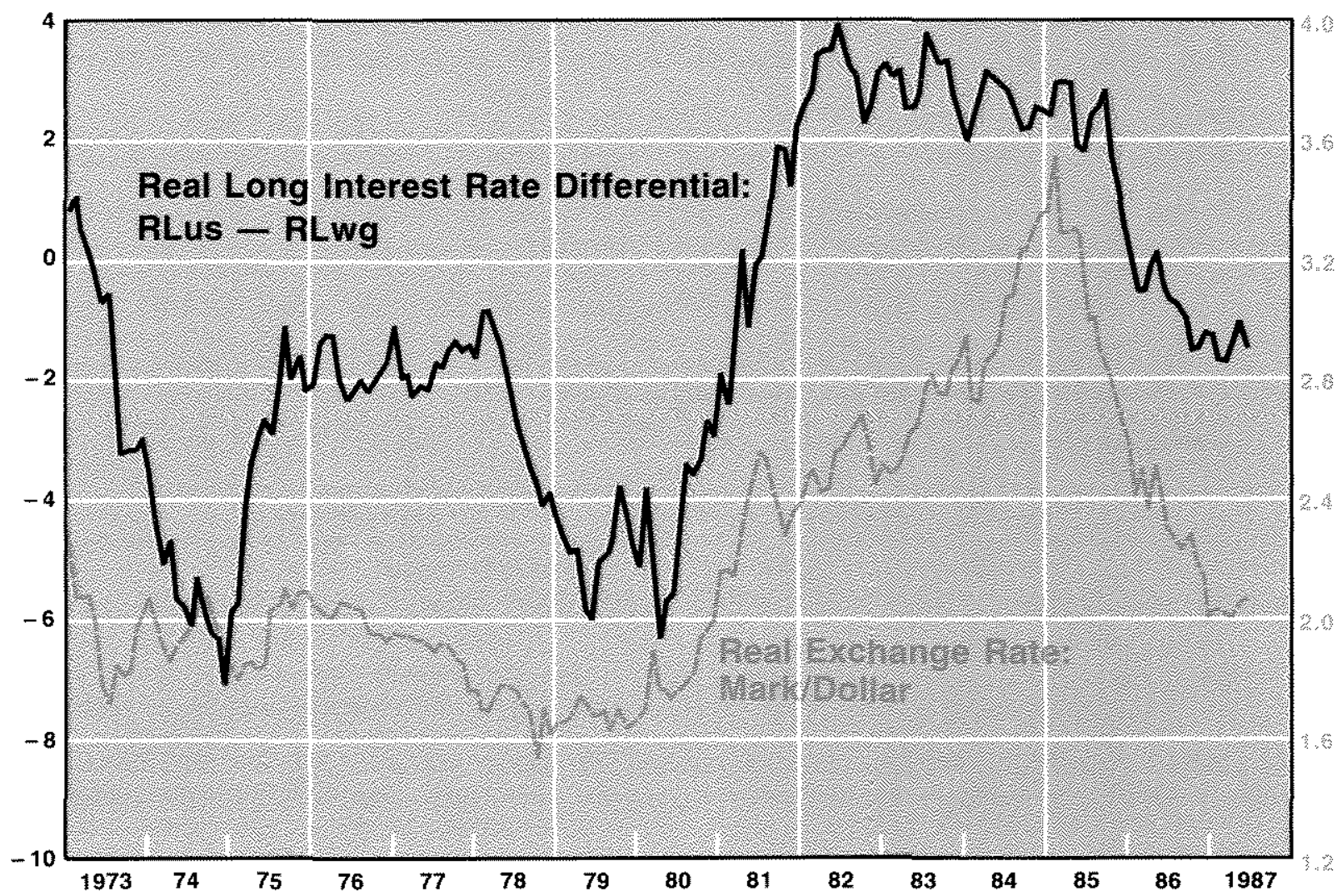

the real exchange rate and differences in real per capita gross national product across countries. On the other hand, the monetary approach seems to have some value in the West German/United States case. An equilibrium relationship appears to exist between the real exchange rate and the difference in long-term interest rates. In view of the low power of unit root tests, this finding is especially noteworthy.

The fact remains that our knowledge of the determination of real exchange rates is meager, at best. The logical question is to ask where research might be directed to expand our knowledge in this area. Numerous explanations, in addition to measurement problems, can be offered for the fact that fundamental variables have not yielded good explanations of real exchange rate movements. One possibility is that the recent period of floating exchange rates is too brief, especially in view of our statistical tools, to draw conclusions about the long-run behavior of real exchange rates. Assuming no change in exchange-rate regime, the passage of time will ultimately rectify this problem. Until sufficient time passes, however, it would be premature to discard the theoretical approaches that have been proposed.

A second possibility is that the existing models are deficient. Our review identified instances in which the assumptions underlying the models did not hold. In addition, since real exchange rates are asset prices, the role of expectations is an aspect of the modeling process that deserves additional scrutiny. The failure of existing models might result from the fact that expectations are formed differently than our models suggest. Consequently, the development of alternative expectations formation mechanisms might prove productive. 
A final possibility is that random shocks of various origins, such as oil price shocks, have moved the real exchange rate. While identification of the real factors that might have affected exchange rates is difficult, Meese and Rogoff (1988) suggest that further attention should be focused on the role of real shocks. Thus, models utilizing modern real business-cycle research might generate some insights. All of these "mights" serve as a final reminder of how little we know.

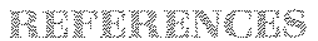

Adler, Michael, and Bruce Lehmann. "Deviations trom Purchasing Power Parity in the Long Run," Journal of Finance (December 1983), pp. 1471-87.

Baillie, Richard T., and Patrick C. Mckahon. The Foreign Exchange Market: Theory and Econometric Evidence (Cambridge University Press, 1989).

Baillte, Richard T., and David D. Selover. "Cointegration and Models of Exchange Rate Determination," International Journal of Forecasting (1987:1), pp. 43-51.

Balassa, Bela. "The Purchasing.Power Parity Doctrine: A Reappraisal," Journal of Political Economy (December 1964), pp. 584-96.

Campbell, John $Y$,, and Richard H. Clarida. "The Dollar and Real Interest Rates," Carnegie-Rochester Conference Series on Public Policy (Autumn 1987), pp. 103-40.

Cox, W. Michael. "A Comprehensive New Real Dollar Exchange Rate Index." Federal Reserve Bank of Dallas Economic Review (March 1987), pp. 1-14.

Cumby, Robert $E_{\text {., }}$ and Maurice Obstfeld. "International interest Rate and Price Level Linkages under Flexible Exchange Rates: A Review of Recent Evidence," in John FO. Bilson and Richard $C$. Marston, eds., Exchange Rate Theory and Practice (University of Chicago Press, 1984), pp. 121-51.

Darby, Michael R. "Movements in Purchasing Power Parity: The Short and Long Runs," in Michael R. Darby and James R. Lothian, eds. The International Transmission of inflation (University of Chicago Press, 1983), pp. 462-77.

Dickey, David A., and Wayne A. Fuller. "Distribution of the Estimators for Autoregressive Time Series With a Unit Root," Journal of the American Statistical Association (June 1979), pp. 427-31.

Dornbusch, Rudiger. "Real Exchange Rates and Macroeconomics: A Selective Survey" Scandinavian doumal of Economics (1989:2), pp. 401-32

"Expectations and Exchange Rate Dynamics," Journal of Political Economy (December 1976), pp. 1161-76.

Dornbusch. Rudiger, and Stanley Fischer. "Exchange Rates and the Current Account," American Economic Review (December 1980), pp. $960-71$.

Dornbusch, Rudiger, and Paul Krugman. "Flexible Exchange Rates in the Short Run" Brookings Papers on Economic Activity (1976:3), pp. 537.75.

Edison, Hali $\mathrm{J}$., and Jan Tore Klovland. "A Quantitative Reassessment of the Purchasing Power Parity Hypothesis: Evidence from Norway and the United Kingdom:" Journal of Applied Econometrics (October 1987), pp. 309-33

Frankel, Jeffrey A. "International Capital Mobility and Crowding-out in the U.S. Economy: Imperfect Integration of Financial Markets or of Goods Markets?" in R.W. Hafer, ed., How Open is the U.S. Economy? (D.C. Heath and Com. pany, 1986), pp. 33-67.
"On the Mark: A Theory of Floating Exchange Rates Based on Real Interest Differentials", American Economic Review (September 1979), pp. 610-22.

Frankel, Jeffrey A., and Richard Meese. "Are Exchange Rates Excessively Variable?" in National Bureau of Economic Research, Macroeconomics Annual 1987, Stanley Fischer, ed. (M/T Press, 1987), pp. 117-53.

Frenkel, Jacob A., and Michael L. Mussa. "Asset Markets. Exchange Raies and the Balance of Payments," in Fonald W. Jones and Peter B. Kenen, eds., Handbook of International Economics (Amsterdam: Elsevier Science Publishers B.V., 1985), pp. $679-747$.

Fuller, Wayne A. Introduction to Statistical Time Series (Wiley, 1976).

Hakkio, Craig S. "Does the Exchange Rate Follow a Random Walk? A Monte Carlo Study of Four Tests for a Random Walk," Journal of International Money and Finance (June 1986), pp. 221-29.

Hooper, Peter, and John Morton, "Fluctuations in the Dollar A Model of Nominal and Real Exchange Rate Determination," Journal of International Money and Finance (April 1982), pp. 39-56.

Hsieh, David A. "The Determination of the Real Exchange Rate." Journal of International Economics (May 1982), pp. 355-62.

Huizinga, John. "An Empirical Investigation of the Long-Run Behavior of Real Exchange Rates," Camegie-Rochester Conference Series on Public Policy (Autumn 1987), pp. 149-214.

Isard, Peter, "An Accounting Framework and Some Issues for Modeling How Exchange Rates Respond to the News," in Jacob A. Frenkel, ed., Exchange Rates and International Macroeconomics (University of Chicago Press, 1983), pp. 19-56.

Koedijk, Kees, and Peter Schotman. "Dominant Real Exchange Rate Movements;" Journal of international Money and Finance (December 1989), pp. 517-31.

Lothian, James R. "A Century Plus of Yen Exchange Rate Behavior," mimeo, New York University.

McNown, Robert, and Myles S. Wallace. "National Price Levels, Purchasing Power Parity, and Cointegration: A Test of Four High Inflation Economies," Journal of international Money and Finance (December 1989), pp. 533-45.

Meese, Richard, and Kenneth Rogoff. "Was If Real? The Exchange Rate-Interest Differential Relation over the Modern Floating-Rate Period," Journal of Finance (September 1988), pp. 933-48.

Sims, Christopher A. "Bayesian Skepticism on Unit Root Econometrics," Discussion Paper 3, institute for Empirical Macroeconomics, Federal Reserve Bank of Minneapolis and University of Minnesota, May 1988.

Tatom, John A. "The Link Between the Value of the Dollar, U.S. Trade and Manufacturing Output: Some Recent Evidence," this Review (November/December 1988), pp. 24-37.

Taylor, Mark P. "An Empirical Examination of Long-Run Purchasing Power Parity Using Cointegration Techniques," Applied Economics (October 1988), pp. 1369-81.

Trehan, Bharat. "The Practice of Monetary Targeting: A Case Study of the West German Experience," Federal Reserve Bank of San Francisco Economic Review (Spring 1988), pp. $30-44$

Whitt, Joseph A. Jr. "Purchasing-Power Parity and Exchange Rates in the Long Run." Federal Reserve Bank of Atlanta Economic Review (July/August 1989), pp. 18-32.

Wolff, Christian C.P. "Time-Varying Parameters and the Outof-Sample Forecasting Performance of Structural Exchange Rate Models," Joumal of Business \& Economic Statistics (January 1987), pp. 87-97. 


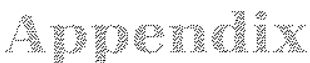

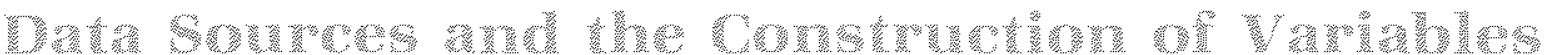

For all variables except interest rates, we use monthly data from International Financial Stalis. tics for June 1973 to June 1988. Recall that $q$ is the log of the real exchange rate with the consumer price index of the respective countries as the deflator. GNP is the log of real gross na. tional product, where nominal gross national product is deflated with the gross national pro duct price deflator. Since gross national product data are not avaitable monthly, we interpolated from quarterly to monthly observations using industrial production. Note that all the potential determinants are defined as differences, with an asterisk indicating the respective value in the other country. PW/PC is the log of the wholesale price index divided by the consumer price index. TB is the cumulated trade balance that is, the sum from January 1972 to time period t of the difference between exports and imports divided by gross national product.

For the interest rates not involving Japan, the time period is June 1973 to June 1987, while for those involving Japan, the time period is July 1977 to June 1987 . The nominal short-term interest rates and their sources are as follows: Japan-one-month Gensaki rate from the Bank of Japan; United Kingdom-one-month inlerbank deposit rate from the Financial Times; West Germany-one-month interbank rate from the Frankfurter Allgemeine Zeitung; and United States-the yield on one-month Treasury bills until April 1984 and, afterward, the interest rate on three-month Treasury bills from the Federal Reserve Board.

The nominal long-term interest fates and their sources are as follows: Japan-average yield to maturity on government bonds with constant remaining maturity of nine years from the Bank of Japan; United Kingdom-average yield to maturity on government bonds with remaining maturity between eight and 12 years from the Financial Times; West Germany-average yield to maturity on government bonds with remaining maturity over eight years from the Frankfurter Allgemeine Zeitung; and United Statesyield to maturity of government bonds with remaining maturity of 10 years from the Federal Reserve Board. We calculated the real shortter'm and long-term interest rates, RS and RL, in the same manner as Meese and Rogoff (1988). Thus, actual inflation rates based on the preceding 12 months as measured by the consumer price index are subtracted from the nominal interest rates to generate the real rates. As a result, the inflation measure does not correspond to the term of the interest rates. A problem with this construction, as well as many others, is that negative real interest rates are computed. For example, the long-term (short-term) real interest rate is negative for 25 (42) percent of the U.S. observations, 38 (30) percent of the British observations, 0 (9) percent of the West German observations and 6 (7) percent of the Japanese observations. 